\title{
A fosszilis puhatestü vázak szerepének kérdése a magyarországi felső paleolitikumban
}

Bálint Csaba

Dobó István Vármúzeum, Eger

E-mail:bcs890321@gmail.com

Kivonat. A magyarországi felső paleolitikum kontextusában legnagyobb mennyiségben előkerült, praktikus funkcióval nem rendelkező leletek a fosszilizálódott harmadidőszaki puhatestű vázak. A kutatás jelenlegi, legelterjedtebb értelmezése szerint ezeket a tárgyakat ékszerként, a szociális identitás kifejezésére használták. Ez a cikk a puhatestű váz leletanyaggal kapcsolatos problémákra próbál rávilágítani. A feltett kérdések érintik a tárgyalt leletanyag nyersanyag forrásainak hatását a korabeli megtelepedésre, a puhatestű váz leletanyagok összetételének egymástól való eltérését és ennek kapcsán a forma szerinti preferenciák szerepét, valamint a tárgyakhoz rendelt funkciók problémáját. A hazai puhatestű váz leletanyagok nagy része a Dunakanyar térségére koncentrálódik. A cikk a földrajzi elhelyezkedés kérdésére is igyekszik felhívni a figyelmet. Konklúziója, hogy az egymástól nagy mértékben eltérő formabeli preferenciákkal rendelkező leletanyagok egymástól eltérő szociális identitást sejtetnek. A viszonylag kis földrajzi térségen belül elterjedésük egy olyan refúgiumnak számító területre utalhatnak, ahol az eltérő önazonossággal Biró csoportok találkozása gyakori lehetett.

Kulcsszavak: felső paleolitikum, művészet, ékszerek, Kárpát-medence, Gravettien

Hivatkozás: Bálint, Cs. (2021). A fosszilis puhatestű vázak szerepének kérdése a magyarországi felső paleolitikumban (The role of mollusc shells in the Carpathian Basin during the Upper Palaeolithic). In N. Faragó, A. Király, \& K. I. Szegedi (szerk.), A tealevelektôl a levélhegyekig. Tanulmányok Mester Zsolt tiszteletére 60. születésnapja alkalmából (pp. 45-61). Litikum \& ELTE BTK Régészettudományi Intézet.

https://doi.org/10.23898/litikumsi01a02

000 LITIKUM KönyVtár 1 
A magyarországi felső paleolitikum legnagyobb mennyiségben előkerült, egyértelmű praktikus funkcióval nem rendelkező leletei a foszszilizálódott, zömében a harmadidőszak során keletkezett puhatestűek meszes vázai. Annak ellenére, hogy ezeknek a túlnyomó része nem volt emberi kéz által megmunkálva vagy módosítva, a szakmán belüli klasszikus értelmezés szerint a begyüjtésük mögött ékszerként való felhasználás szándéka húzódik (Gábori, 1969, 8. o). Jelenlétük a felső paleolit leletanyagban a több esetben bizonytalan funkción túl egyéb kérdéseket is felvet. Ennek a tárgytípusnak a vizsgálata potenciálisan új dimenziókat nyithat a kutatásban, és kiegészítheti a korszakról alkotott képünket. Jelen tanulmány célja rávilágítani, hogy a korabeli emberek életében ezek a tárgyak milyen szerepet töltöttek be, az alábbi kérdések alapján:

A puhatestű vázak nyersanyagforrásainak elérhetősége közre játszott-e a térségben való megtelepedéshez? Az elérhetőség mennyiben befolyásolhatta az értéküket?

Tetten érhető-e a tárgyak formai spektruma alapján egy lelőhelyeken átívelő rendszeresség, melynek segítségével körvonalazhatóak hasonló preferenciákkal rendelkező csoportok?

Valóban tekinthetőek e ékszerek alapanyagának, felvethető-e esetleg egyéb praktikus funkció?

Magyarországon belül miért egy viszonylag kis földrajzi területre koncentrálódnak a fosszilis puhatestű vázak?

A kérdések megválaszolásában nagy segítséget nyújtanak a tárgyalt jelenségek egykorú külföldi párhuzamai és a szóban forgó leletanyagokkal kapcsolatos kutatási eredmények.

\section{A tárgyalt leletanyag}

Magyarországról összesen tizennégy felső paleolit lelőhelyen, szinte kizárólag Gravettien környezetben kerültek elő ember által gyűjtött fosszilis puhatestű vázak. Ezek közül tizenegy a Dunakanyar térségében vagy annak legfeljebb 30 km-es sugarú körzetén belül található (1. ábra). A kivételt Tarcal-Citrombánya, Jászfelsőszentgyörgy-Szunyogos, valamint Ságvár-Lyukas-domb képezik. A legtöbb ilyen tárgy a T. Dobosi V. által kidolgozott kronológiai rendszer szerint a kavics-gravetti kultúrába (19000-17000BP) (T. Dobosi, 2009) sorolható Szob-Ipolyparton került elő, összesen 398 darab (Dulai, 2007, 24. o. Table 1 táblázatában 398 darab fosszilis puhatestü váz van részletezve, Markó et al., 2018, 234 .o. Table 3 táblázatban már csupán 397 darabot említ) (2. ábra). Száz körüli darabszámmal két lelőhely, a szintén kavics-gravetti Mogyorósbánya-Újfalusi-dombok (95 darab) (3. ábra) és az Epigravettien (18000-12000 BP) Esztergom-Gyurgyalag (91 darab) (4. ábra) rendelkezik. Tíz fölötti darabszámmal az Epigravettien Pilismarót-Pálrét (11 darab) bír. Tíz vagy az alatti mennyiségű fosszilis puhatestű váz öt lelőhelyről (Pilismarót-Bitóc, Verseg-Kertekalja, Ságvár-Lyukasdomb, Csővár-barlang, Tarcal-Citrombánya), további ötről pedig csak egy-egy darab ismert (Jászfelsőszentgyörgy-Szunyogos, Vác-Kishermányi út, Bivak-barlang, Pilisszántó I. kőfülke, Nagykovácsi, Remete-felső-barlang) (Markó et al., 2018, Table 1, Table 3; T. Dobosi \& Vörös, 1984; T. Dobosi, 1985; Gáboriné-Csánk, 1984). Tekintve, hogy a Dunakanyartól viszonylag távol eső, földrajzilag egymástól is elkülönülő három lelőhelyen (Tarcal, Jászfelsőszentgyörgy, Ságvár) minimális mennyiségű, összesen 8 darab fosszilis puhatestű váz került csupán elő (T. Dobosi, 1985, 1993; Lengyel, 2010; Markó et al., 2018, Table 3), a továbbiakban a vizsgálatom fóként a Dunakanyarra fog koncentrálni (1. ábra). Ez az észak-közép-magyarországi terület számos, puhatestű és egyéb állati illetve növényi maradványok fosszíliáit rejtő harmadidőszaki kiemelkedést tartalmaz. Egy részük feltételezhetően nyersanyagforrásként hasznosult a felső paleolitikum során (Dulai, 2007, Table 1; Markó et al., 2018). Megjegyzendő, hogy számos esetben a puhatestű vázak keletkezését tekintve nehéz eldönteni, hogy fosszilis, harmadidőszaki 


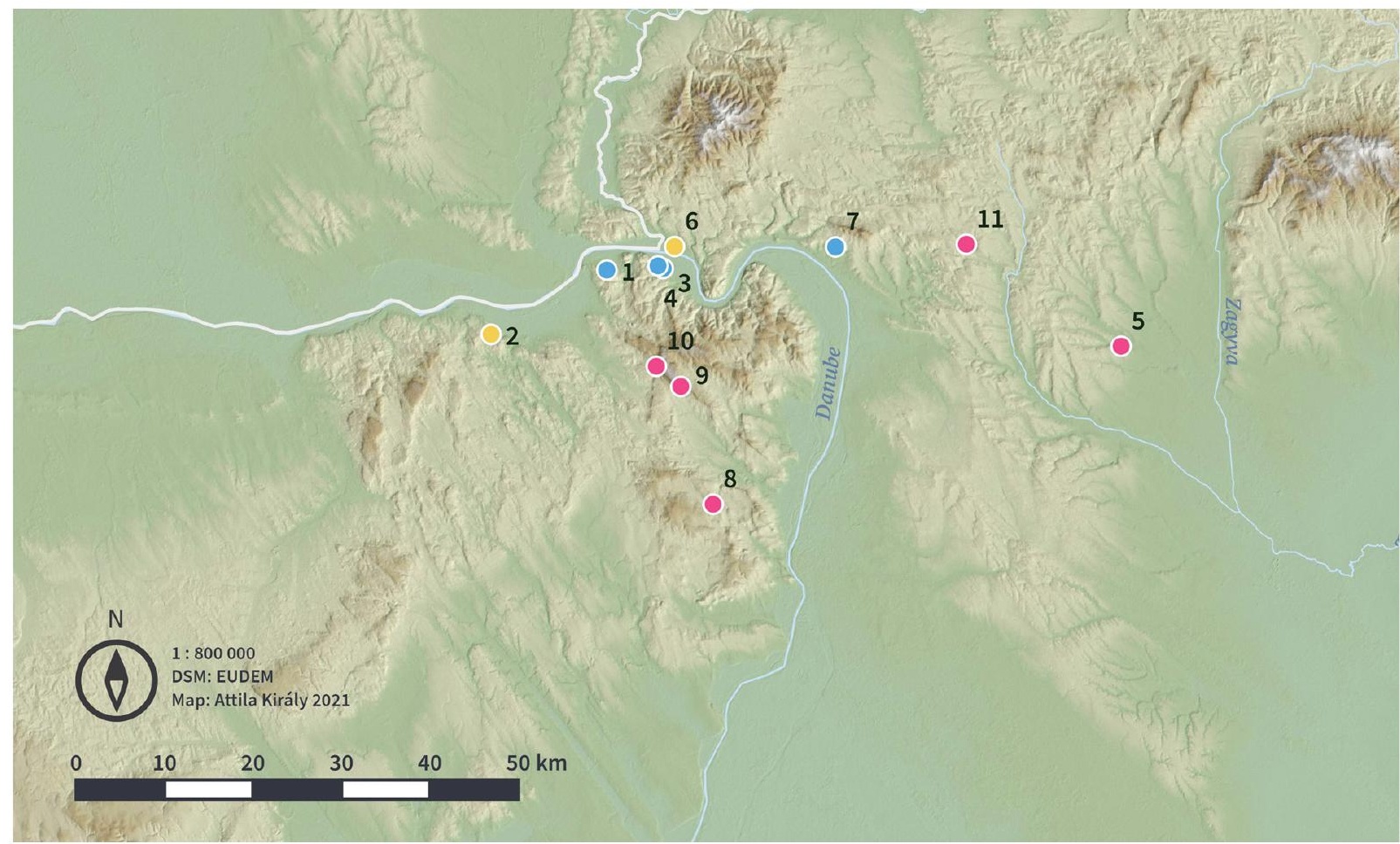

1. ábra. A Dunakanyar térségében található felső paleolit lelőhelyek, melyek leletanyaga fosszilis puhatestű vázat tartalmazott. Jelagyarázat: 1 - Esztergom-Gyurgyalag, 2 - Mogyorósbánya-Újfalusi dombok, 3 - Pilismarót-Bitóc, 4 - Pilismarót-Pálrét, 5 - Verseg-Kertekalja, 6 - Szob-Ipolypart, 7 - Vác-Kishermányi út, 8 - Nagykovácsi, Remete-barlang, 9 - Pilisszántói I. kőfülke, 10 - Bivak-barlang, 11 - Csővár-barlang. A színek T. Dobosi 2009 kronológiai rendszerének besorolását jelölik. Kék jelölő: Epigravettien, zöld: kavics-gravetti, fehér: pavlovi kultúra vagy kulturálisan nehezen beazonosítható. (Térkép: Király Attila).

geológiai forrásokból származó vagy szubrecens, tengerparton gyüjtött darabok kerültek elő a felső paleolit lelőhelyeken. Az egyes darabok eredetének kérdéseire döntő választ természettudományos vizsgálatok adhatnak (Vanhaeren et al., 2004). Magyarországi viszonylatban a tengerparti területek messzesége miatt nem sok kétség füződik hozzá, hogy a leletanyag főleg fosszilis vázakat tartalmaz, azonban külföldi analógiák alapján elképzelhető, hogy egy-egy darab távoli, szubrecens forrásokból kerülhetett hazai lelőhelyre.

A fosszilis puhatestű vázakkal Biró lelőhelyek datálását tekintve egyértelműen látszik, hogy $\mathrm{T}$. Dobosi V. rendszere szerint a legtöbb a kavics-gra- vetti és az Epigravettien kulturális-kronológiai horizontokba sorolható. Ez természetesen következhet abból a tényből, hogy a kutatás jelenlegi állása szerint a Dunakanyar térségéből nem nagyon ismerünk a Gravettien entitás idősebb pengés fílumába (28000-26000 BP) sorolható lelőhelyeket (T. Dobosi \& Holl, 2013). A Kárpát-medence környékén, pl. Dél-Morvaországban már a pavlovi kultúra ideje alatt is népszerűek voltak ezek a tárgyak (Hladilová, 2005). Ebből akár arra is következtethetünk, hogy ebben az időszakban a Dunakanyar térségében található források még nem voltak ismertek. 
2. ábra. Szob-Ipolypart puhatestű váz leletanyagának nemek szerinti megoszlása (a csupán 1 $\mathrm{db}$-al rendelkező nemek összevonva) (Dulai 2007, Table 1 alapján)

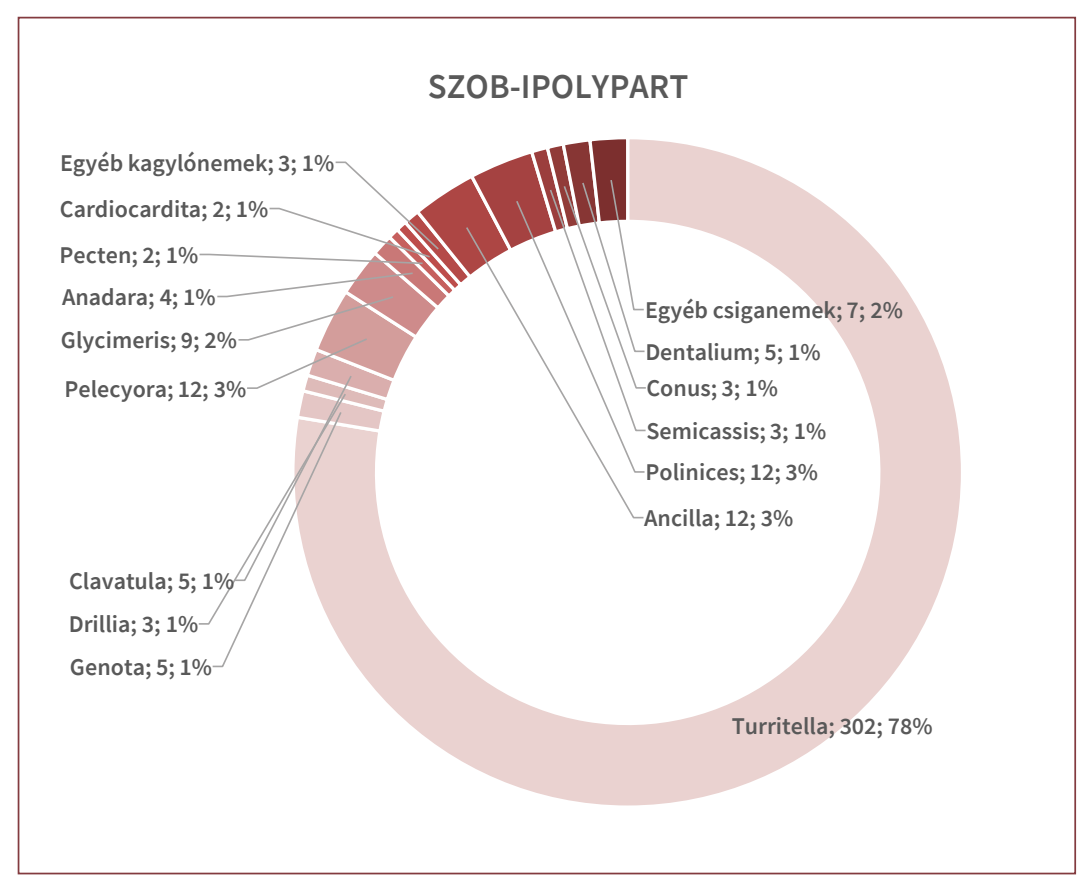

Lengyel Gy. újabb kronológiai rendszere a magyarországi Gravettien entitást illetően eltérő képet mutat a fent említett lelőhelyek besorolásáról. A hazai anyagban az idősebb pengés fílumnak is nevezett pavlovi kultúrával valójában nem számolhatunk, csupán a 25000 és 21000 BP közé datálható késő Gravettiennel. Lengyel Gy. rendszerében Szob, Mogyorósbánya és a pilismaróti lelőhelyek az utolsó hidegmaximummal egybeeső korai Epigravettienbe (21000-17000 BP) lettek helyezve, Esztergom pedig a késői Epigravettienbe (17000-13000 BP) (Lengyel, 2018).

Nemek tekintetében az egyes lelőhelyek foszszilis vázai feltűnő eltérést mutatnak (1. táblázat, 2-4. ábra). A száz fölötti vagy az akörüli darabszámmal rendelkező leletanyagok közül mindegyik esetében más a vezető csiganem. Az eltérés még olyan, egymástól nem nagy távolságra (kb. $20 \mathrm{~km}$ ) található lelőhelyek között is feltűnő, mint Szob és Mogyorósbánya, melyek ugyanabba a kulturális fílumba tartoznak (Markó et al., 2018).

\section{Puhatestü vázak forrásainak elérhetősége}

Egy adott térségen belüli korabeli megtelepedésben, ha nem is kizárólagos indokként, de bizonyos mértékig közre játszhatott a feltehetően ékszerekhez használt puhatestű váz nyersanyagok fellelhetőségének közelsége. Ez külföldi lelőhelyekkel, például a görögországi Franchthi-barlanggal kapcsolatban is felmerült (Baysal, 2019). A nyersanyagforrás szomszédsága miatt ez a tényező olyan hazai lelőhelyek, mint Szob-Ipolypart, Esztergom-Gyurgyalag, Pilismarót-Pálrét valamint Mogyorósbánya-Újfalusi-dombok esetében is lehetséges. A Dunakanyar térségének sűrű megtelepedésére ez a tényező már T. Dobosi V. és Kövecses-Varga E. (1991) számára is felmerült indokként esztergomi kutatásaik kapcsán. Szobon a nagy mennyiségü módosítatlan váz előfordulása a nyersanyagforrások közelségével is magyarázható. Mogyorósbánya esetéből kiindulva a térségben lévő települések egy része azonban nem csupán egy közeli nyersanyagforrást aknázott ki a puhatestű vázak beszerzésére (Markó et al., 2018). 


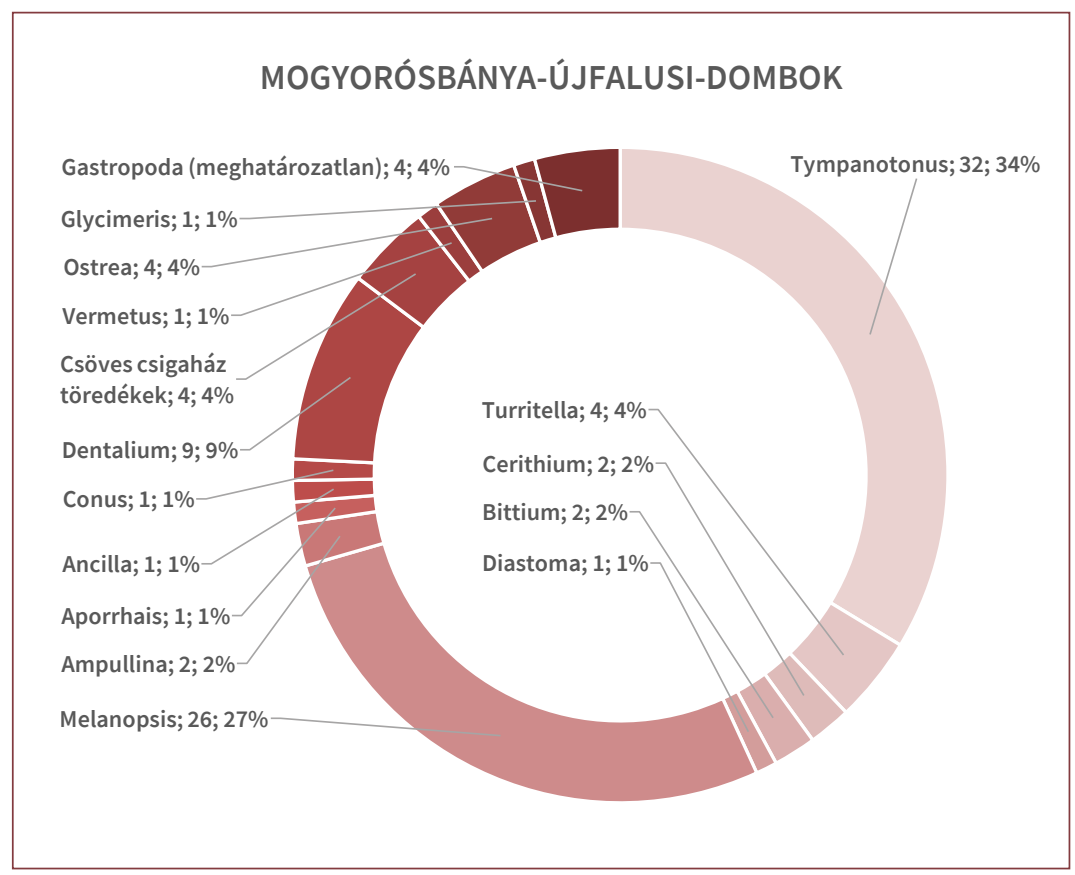

3. ábra. Mogyorósbánya-Újfalusi dombok puhatestű váz leletanyagának nemek szerinti megoszlása (Markó et al. 2018, Table 1 alapján).
A hazai leletanyag alapján a felső paleolitikum közösségei csak a lokális forrásokból származó puhatestű vázakat használták. Az egzotikus kovakő nyersanyagokhoz hasonlóan azonban arra is ismerünk példát Európa egyéb területeiről, hogy a fosszilis vagy szubrecens puhatestü vázak messzi területekről kerültek egy-egy lelőhelyre. Ennek a tárgytípusnak a mozgatása, figyelembe véve méretét és csekélynyi súlyát, még a kova nyersanyagoknál is egyszerűbb. A Kárpátok keleti lábánál található romániai Poiana Cireşului-Piatra Neamț lelőhely Gravettien III-as rétegében (26000-27000 uncal. BP) előkerült átfúrt csigaházak a legközelebb, kb. 800 km-re található Égei-tenger partvidékéről származnak, ugyanakkor már minden bizonnyal késztermékként érkeztek a területre (Nițu et al., 2019). Délnyugat-Németország Magdalénien lelőhelyein előkerült fosszilis és szubrecens puhatestű vázak több, különböző távolságokra lévő területekről származnak (Eriksen, 2002, Fig. 12). A viszonylag közelinek mondható forrásokon kívül a mintegy 250 km-re található Mainzi-medence, az 500 km-re található Párizsi-medence, illetve a még annál is távolabb lévő atlanti és mediterrán partvidékekről is érkeztek tárgyak. B. V. Eriksen a Mainzi-medencével való kapcsolatok egyik lehetséges magyarázataként a Délnyugat-Németországban feltételezett alaptáborokba az időnként északi irányból érkező közösségeket veti fel. A távolsági kapcsolatok egy része különböző térségeken átivelő hálózatok mentén szerveződött, melyben elsősorban a szomszédos közösségek kommunikáltak egymással (Eriksen, 2002, Fig. 12). A délnyugat-franciaországi Peyrazet felső Magdalénien telepén feltárt puhatestű vázak, mint pl. Dentalium és Glycymeris darabok az akkori alacsonyabb tengerszint miatt $300 \mathrm{~km}$-re található atlanti és a mediterrán partvidékekről származnak. S. Rigaud és szerzőtársai a beszerzésüket szintén kiterjedt hálózatokkal magyarázzák (Rigaud et al., 2019).

B. V. Eriksen meglátása szerint a közvetlen beszerzés ilyen kis tárgyak esetében túl nagy energiabefektetést jelenthetett. A helyi és távolsági forrásokból származó puhatestű vázak gyűjtése 
4. ábra. Esztergom-Gyurgyalag puhatestű váz leletanyagának nemek szerinti megoszlása (Magyar 1991, 265 alapján).

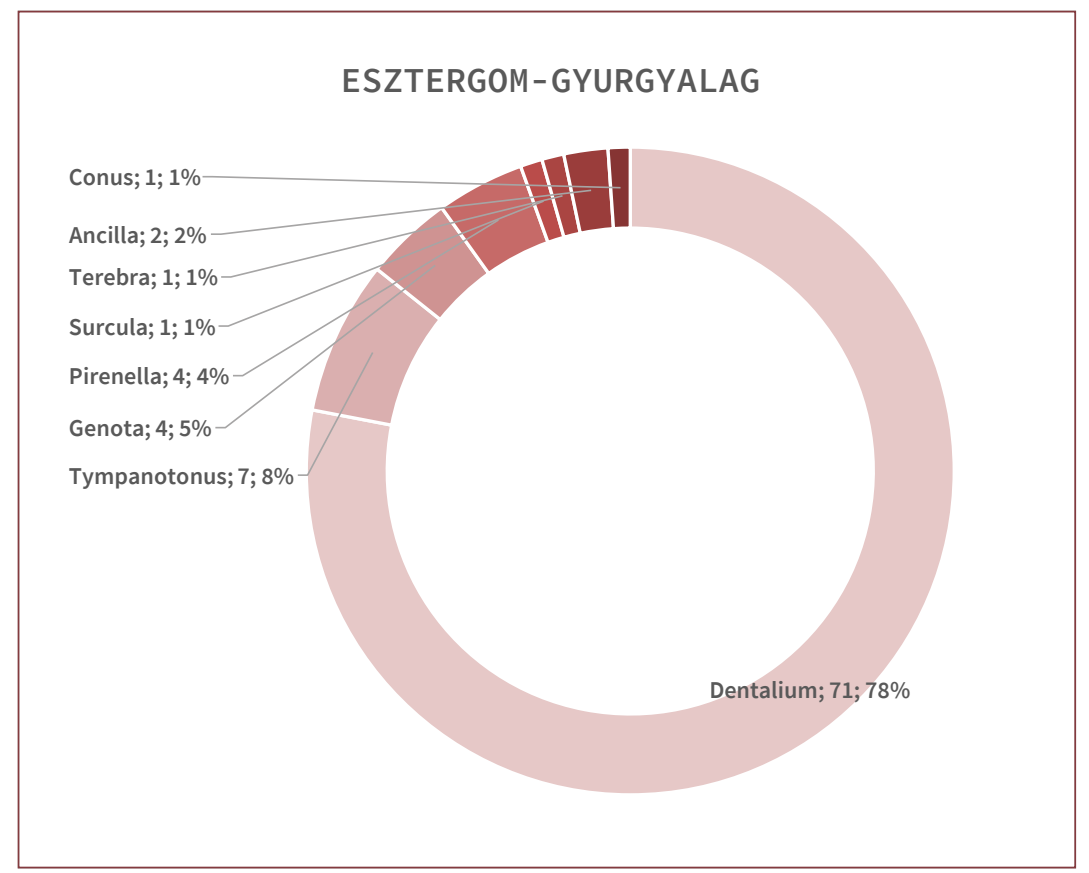

Délnyugat-Németország esetében a közösségek szezonális mozgásának keretében történő egyéb beszerzési tevékenységekbe lehetett ágyazva (Eriksen, 2002). Ezt a képet árnyalhatja, hogy a korabeli csoportok számára az egyes puhatestű vázak milyen értéket képviseltek. Elképzelhetőnek tartom, hogy ha az adott vázak hangsúlyos szerepet játszottak a közösség életében, akkor a közvetlen beszerzés bizonyos esetekben (pl. rendkívüli események a csoport életében) vállalható befektetés volt. Az érték koncepciója természetesen rendkívül változó és sok tényezőtől függ, legyen az a távolság, a beszerzés nehézsége, szín, forma, más közösségek kereslete a tárgy iránt stb. (Baysal, 2019). Láthatunk példát arra, hogy puhatestü vázak beszerzésére két forrás közül a távolabbit választották. M. Vanhaeren és szerzőtársai stroncium izotópos vizsgálat segítségével állapították meg, hogy az 1926-ban feltárt La Madeleine gyermektemetkezéséből előkerült csigaház-ékszerek alapanyaga nem a korábban felvetett közelebbi, mintegy 80 km-re található miocén kibúvásból, hanem (beleszámolva a tengerszint akkori magasságát) az attól kb. 50 km-el távolabb lévő atlanti partvidékről származott. A távolabbi forrás választása mögött nagyrészt morfometriai indokok álltak, hiszen a miocén Dentalium csigaházak átmérője nem elég nagy ahhoz, hogy a La Madeleine lelőhelyen előkerült, felfüzéshez használt csonttűk átférjenek a méretre vágott darabokon (Vanhaeren et al., 2004).

Az érték szempontjából fontos tényező lehetett, hogy az adott puhatestű vázakhoz a közösség közvetlenül a forrásnál, vagy más közösségeken keresztül jutott hozzá. Ebben a tekintetben azok a közösségek, akik a nyersanyagforráshoz könynyen fértek hozzá, majd megmunkáltan vagy akár módosítatlanul tovább adták a félkész darabokat, az értéket maga a cserével létrejött kulturális interakció valamint az ellenértékként kapott javak jelenthették. Talán a Dunakanyar térségében talált kisszámú kialakított ékszer hátterében is hasonló indok húzódhatott, ebben az esetben viszont egyfajta csereeszköz funkció felmerülhet. 


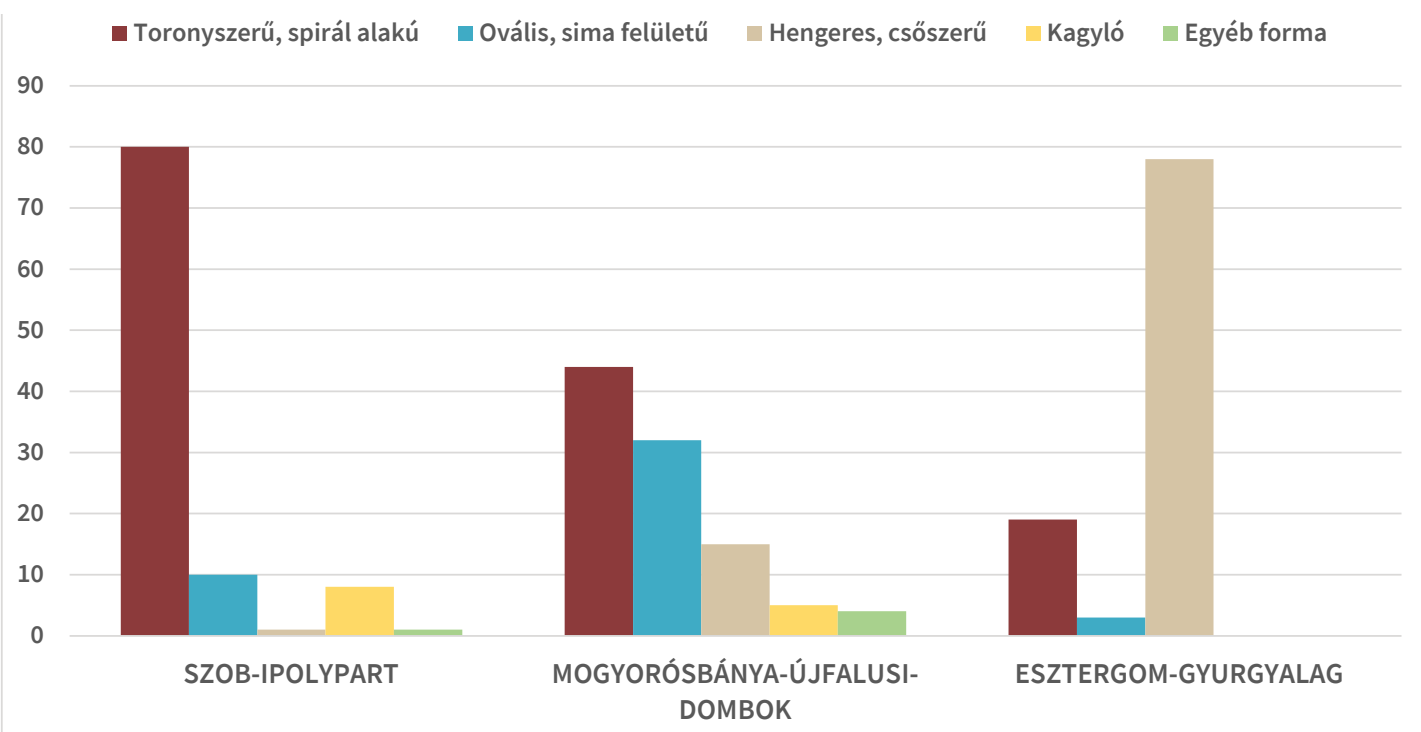

5. ábra. A vizsgált lelőhelyek puhatestű váz leletanyagának forma szerinti megoszlása. Szob-Ipolypart esetében a Charonia, Murex és Strombus nemekbe sorolható darabok szerkezete spirálos alakú, azonban rövidebb, tömzsi formájuk alapján nem helyeztem őket a hosszúkás darabokat tartalmazó 'Toronyszerü, spirál alakú' kategóriába (Magyar Nemzeti Digitális Archívum, n.d. a, n.d. b, n.d. c). Szob-Ipolypart adatok: Dulai, 2007, Table 1. Mogyorósbánya-Újfalusi dombok adatok: Markó et al., 2018, Table 1. Esztergom-Gyurgyalag: Magyar, 1991, 265.

A Dunakanyar megtelepedésével kapcsolatban érdemes szem előtt tartani a felső paleolitikus közösségek változó mértékű mobilitását is (Lengyel, 2018). Az ebből fakadóan felmerülő kérdés, hogy ezekhez a nyersanyag-forrásokhoz közeli telepek mennyiben számítottak periférikus, időszakosan látogatott térségeknek olyan központinak számító, refúgiumként is értelmezett területekhez képest, mint Dél-Morvaország térsége. Észak-Közép-Magyarország Gravettien lelőhelyei nem rendelkeznek az összes jellegzetességgel, amit A. Wiśniewski és szerzőtársai a központi területek kritériumaiként feltüntetnek, mint pl. a temetkezések vagy a geometrikus művészet (Wiśniewski et al., 2015, Table 6). Lengyel Gy. ennek ellenére számol azzal, hogy a korai Epigravettien során az eurázsiai jégtakaró legnagyobb kiterjedésével a Kárpát-medence is refúgium területté válhatott, melyre a távolsági (transzkárpáti) kőnyersanyagok alacsony aránya is utalhat (Lengyel, 2018).
A térség állandó jellegű megtelepedése az utolsó hidegmaximum során azzal is összefügghet, hogy a fosszilis puhatestű vázakat tartalmazó leletanyagok nagy része szintén a korai Epigravettienre keltezhető Lengyel Gy. rendszere szerint.

Ahogy A. Wiśniewski és munkatársainak kutatása rámutatott, egy adott területen való megtelepedést nehéz meggyőzően egy bizonyos tényezőhöz kötni, tekintve, hogy számos környezeti, klimatikus és szociális jellemző függvénye volt (Wiśniewski et al., 2015). Bizonyos mértékig a puhatestű vázak beszerezhetősége közrejátszhatott a Dunakanyar benépesítésében, értékük azonban az elérhetőségtől függően idővel átalakulhatott. A késői Epigravettien időszakában Lengyel Gy. felvetése szerint a közösségek életvitelére a nagy távolságokat felölelő mobilitás vált jellemzővé, és elsősorban ideiglenes táborokkal lehet számolni (Lengyel, 2018, 148). Ez utalhat arra, hogy a foszszilis puhatestű vázak (valamint a kovanyersanya- 
gok) elérhetőségének nem volt olyan döntő szerepe a korabeli emberek számára, hogy felülírja vagy akár nagymértékben befolyásolja a mobil életmódot.

\section{Formai szempontok}

Azért, hogy közelebb kerüljünk azokhoz a szempontokhoz, ahogy a felső paleolitikum során tekinthettek a puhatestű vázakra, a modern rendszertani felosztásoknál tágabb, egyszerübb kategóriákra van szükségünk. Egy ilyen csoportosítást Š. Hladilová végzett el korábban a morvaországi Pavlov I lelőhelyén előkerült fosszilis puhatestű vázakkal kapcsolatban (Hladilová, 2005). Rendszerében az általános formatípusokat alak és felület szerint határozta meg. Az első csoport a sima felületű, tojásdad alakú vázaké, melyek közé pl. a magyarországi leletanyagban is meglévő kúpcsigák családjába tartozó Conus-t vagy a szurokcsigák családjába tartozó Melanopsis-t sorolta. A következő a hosszúkás, toronyszerűek csoportja, melyek közé a toronycsigát (Turritella) sorolta, Szob-Ipolypart leletanyaga ilyen példányokban bővelkedik. A harmadik a hengeres, csőszerű vázak csoportja, melyek közül leginkább említésre méltó a magyarul agyarcsigának is nevezett Dentalium. Utóbbi a legnagyobb számban Esztergom-Gyurgyalag leletanyagában képviselteti magát. A negyedik kategóriába a bordás felületű kagylók tartoznak, ilyenek a Szob-Ipolyparton kis számban előforduló Anadara és Cardium kagylók.

Ez a csoportosítás a Dunakanyar leletanyagai esetében is kirajzolja az egyes lelőhelyek közösségeinek preferenciáit (5. ábra). Š. Hladilová rendszerét, kiváltképp az első kategóriát, formai szempontok alapján további kategóriákra lehetne bontani, hiszen a benne foglalt fajták a korabeli ember számára is feltűnően eltérő formákkal rendelkeznek. Ilyen alcsoportot képezhetnek például a kúpcsiga (Conus) nembe sorolható fajok, melyek oldalnézetben lekerekített sarkú deltoid alakúak (Peters et al., 2013, Fig. 1 illusztráció alapján), míg az Ancilla nembeliek ellipszis vagy lencse formájúak (Kilburn, 1981, Fig. 71-78 illusztrációk alapján). Ugyan forma, felület és akár méret alapján felvethetőek további vagy újabb kategóriák is, beható malakológiai ismeretek hiányában egy eltérő rendszer felállítására nem teszek kísérletet. Markó A. és szerzőtársai ezeket a kategóriákat némileg leegyszerűsítve alkalmazták a hazai leletanyagra és az első két kategóriát csak felület alapján határozták meg egyszerű (simple) és díszített (ornamented) felülettel rendelkezőkre. Rendszerükben a bordás felületű kagylók kategóriát általánosan használták az összes kagylóra (Markó et al., 2018, Table 3). A Š. Hladilová által felvázolt négy kategória szerinti felosztást tartom a továbbiakban szem előtt, a Markó A. által is felvetett kagyló kategória kiszélesítésével.

A formai kategóriák arányai szerint a Dunakanyarban előkerült négy legnagyobb puhatestű váz leletegyüttes a felosztását lásd az 1. táblázatban.

\section{Csoportok elkülönítése összetétel alapján}

Amennyiben az ékszerekként használt tárgyak több darabból álló nyakláncok elemei, vagy a felső paleolitikus temetkezések alapján sapkákhoz, vagy a viselet egyéb elemeihez rögzített díszek voltak, érdemes lehet nagyobb egységekként tekinteni rájuk (Bahn, 2016, 131. o.). Ebből kiindulva a leletanyagokban felismert egykori formai preferenciák kiemelten fontosak lehetnek.

A Dunakanyar térségében található Gravettien fosszilis puhatestű váz együttesek egymáshoz képest nagy heterogenitást mutatnak. Joggal merülhet fel a kérdés, hogy mi okozza ezt a nagymértékű eltérést a forma iránti preferenciákban egymáshoz viszonylag közeli lelőhelyek között. A bizonyos lelőhelyek között közre játszhat az időbeli eltérés. Ha megnézzük Dél-Európa folyamatos megtelepedéssel rendelkező lelőhelyeit, mint pl. Riparo Mochi vagy Klissoura, láthatjuk, hogy a felső paleolitikum során az ékszercsiga együttesek forma és nem szerint egy adott lelőhelyen 
belül többnyire változatlanok maradtak, vagy csak kis mértékben változtak (Stiner, 2014, 55. o., Fig. 4). További kérdésre adhat okot Szob és Mogyorósbánya fosszilis puhatestű váz összetételeinek már említett eltérése.

A hazai lelőhelyekhez hasonló szintü heterogenitás Dél-Morvaország pavlovi kultúrájának telepei esetében is tetten érhető (1. táblázat). Pavlov I anyagában a hengeres, csőszerü darabok, mint pl. a Dentalium az együttes 56\%-át teszik ki, Pavlov II esetében a toronyszerűek dominálnak 60\%-al, Pavlov VI anyaga pedig már sokkal kiegyensúlyozottabb, a toronyszerű, csőszerű és az ovális, sima felületűek ugyanakkora, 30\% körüli arányt tesznek ki. Érdemes talán észben tartani ezeknél a lelőhelyeknél, hogy egymáshoz rendkívül közel, pár száz méter távolságra találhatóak, illetve eltérő mennyiségü puhatestű vázból állnak az együttesek (Pavlov I 672 darab töredékek nélkül, míg Pavlov II csupán 67 darab) (Hladilová, 2005, Table 1, 384. o. 2011, Table 1). Š. Hladilová az eltérő arányokat a nyersanyagforrások hozzáférhetőségének geológiai viszonyok miatti változásával magyarázza, semmint kulturális átalakulással (Hladilová, 2011, 58, 59. o.). Persze nem kizárható, hogy a nyersanyagforrások hozzáférhetőségének változása közrejátszott bizonyos kulturális szokások megváltozásában. A nézetet, miszerint a nyersanyag elérhetősége alapvetően befolyásolta az ékszerkészítés szokását, M. C. Stiner is osztja (Stiner, 2014, 54. o.). A moldovai, Prut és Dnyeszter menti, 26000-27000 uncal. BP, valamint 17000 uncal. BP környékére datált lelőhelyek esetében szintén nagymértékű a heterogenitás az ékszerek között. Egy részük nyersanyaga itt nem puhatestű váz, hanem többek között állatfog és mamutcsont. A különbségek kifejezetten szembetűnőek, ha a már fent említett Poiana Cireşului-Piatra Neamț lelőhely mediterrán térségből származó ékszereivel vetjük össze (Cârciumaru et al., 2019). A hazai Epigravettiennel egyidős dél-németországi Magdalénien lelőhelyek (1. táblázat) (pl. Peters- fels, Hohle Fels) szubrecens és fosszilis puhatestü vázai összetételben ugyancsak eltérő arányokat mutatnak. Közös vonásként azonban a kagylók, főleg a Glycymeris iránti preferencia kimutatható (Eriksen, 2002).

Ha a szinte állandó jelleggel lakott dél-európai lelőhelyek, mint Riparo Mochi példájából indulunk ki, feltételezhető, hogy egy adott közösség ékszerkészítési tradíciói alig változtak több évezreden keresztül. Ebből adódóan egy-egy földrajzi térségen belül az eltérések indoka az egymástól eltérő szokásokkal rendelkező közösségek jelenléte lehet. Kapcsolatuk egymással a mobilitásuktól függött. Ahogy E. Baysal rámutatott, a felső paleolitikum nagymértékben mozgékony közösségei számára az érintkezés útvonalak és nem pedig állandó telepek alapján szerveződött, az általunk értelmezett közelség nem volt elsődleges szempont (Baysal, 2019, 55). Ez hazai tekintetben is fontos szempont lehet, föleg ha figyelembe vesszük a földrajzi akadályokat, mint pl. a Szobot és Mogyorósbányát egymástól elválasztó Dunát. Ebből kifolyólag nem feltétlenül meglepő, ha nem látunk közös nevezőt a nagyobb mennyiségű puhatestü vázzal rendelkező leletanyagok között a formák szempontjából. Egy feltűnő jellegzetesség, amit Esztergom, Pilismarót, Pálrét, és Pilismarót, Bitóc felső rétege alapján látunk, a csőszerü darabok, többnyire a Dentalium kedveltsége, ám ez egybevág a felső paleolitikum végén látható általános tendenciával (Markó et al., 2018, Table 3; Stiner, 2014).

\section{A fosszilis puhatestű vázak funkciói}

A felső paleolitikus lelőhelyeken előkerülő fosszilis illetve szubrecens csiga- és kagylóhéjak elterjedt értelmezése, hogy dekoratív tulajdonságaik miatt ékszerként voltak használva, vagy ilyen használatot szántak nekik (Bar-Yosef Mayer, 2005; T. Dobosi, 1985; Eriksen, 2002). Ez a hazai leletanyag esetében vita tárgyát képezheti, tekintve, hogy egy sem került elő olyan kontextusban (pl. 
1. táblázat. A dél-morvaországi Pavlovien, a Dunakanyar környéki Gravettien és a délnyugat-németországi Magdalénien lelőhelyek puhatestű váz leletanyaga Š. Hladilová által felvázolt formabeli rendszerbe rendezve (az általa nem említett csiganemeket általános formái alapján soroltam a meglévő kategóriák egyikébe. A leletanyag közvetlen vizsgálatával így ez változhat) (T. Dobosi, 1985, 25, 28. o.; Hladilová, 2005, Table 1., 378-384. o., 2011, Table 1, Table 2; Dulai, 2007, Table 1; Markó et al., 2018, Table 1; Magyar, 1991, 265. o.; Eriksen, 2002, Table 2).

\begin{tabular}{|c|c|c|c|c|c|c|c|c|c|c|c|c|}
\hline \multirow[t]{2}{*}{ Régió } & \multirow[t]{2}{*}{ Lelőhely } & \multicolumn{2}{|c|}{$\begin{array}{l}\text { Toronyszerü, } \\
\text { hosszúkás, } \\
\text { spirál alakú }\end{array}$} & \multicolumn{2}{|c|}{$\begin{array}{l}\text { Hengeres, } \\
\text { csőszerü }\end{array}$} & \multicolumn{2}{|c|}{$\begin{array}{l}\text { Ovális, sima } \\
\text { felületű }\end{array}$} & \multicolumn{2}{|c|}{ Kagylók } & \multicolumn{2}{|c|}{$\begin{array}{l}\text { Egyéb } \\
\text { formák }\end{array}$} & J̈sszes \\
\hline & & $\mathrm{db}$ & $\%$ & $\mathrm{db}$ & $\%$ & $\mathrm{db}$ & $\%$ & $\mathrm{db}$ & $\%$ & $\mathrm{db}$ & $\%$ & $\mathrm{db}$ \\
\hline \multirow{5}{*}{$\begin{array}{l}\text { Dél-Morvaor- } \\
\text { szág (pavlovi } \\
\text { kultúra) }\end{array}$} & Dolní Věstonice & 8 & 15 & 35 & 66 & 10 & 19 & 0 & 0 & 0 & 0 & 53 \\
\hline & Pavlov la & 124 & 18 & 377 & 56 & 64 & 10 & 94 & 14 & 13 & 2 & 672 \\
\hline & Milovice IV ${ }^{b}$ & 6 & 17 & 11 & 30 & 10 & 28 & 5 & 14 & 4 & 11 & 36 \\
\hline & Pavlov II & 40 & 60 & 19 & 28 & 9 & 9 & 2 & 3 & 0 & 0 & 67 \\
\hline & Pavlov $\mathrm{VI}^{\mathrm{b}}$ & 55 & 39 & 43 & 31 & 40 & 29 & 0 & 0 & 2 & 1 & 140 \\
\hline \multirow{4}{*}{$\begin{array}{l}\text { Dunakanyar } \\
\text { (kavics- } \\
\text { gravettien és } \\
\text { Epigravettien) }\end{array}$} & Szob, Ipolypart & 317 & 80 & 5 & 1 & 41 & 10 & 32 & 8 & 3 & 1 & 398 \\
\hline & $\begin{array}{l}\text { Mogyorósbánya, Újfalusi } \\
\text { dombok }\end{array}$ & 41 & 44 & 14 & 15 & 31 & 32 & 15 & 5 & 4 & 4 & 95 \\
\hline & Esztergom, Gyurgyalag & 17 & 19 & 71 & 78 & 3 & 3 & 0 & 0 & 0 & 0 & 91 \\
\hline & Pilismarót, Pálrét & 2 & 17 & 9 & 75 & 0 & 0 & 0 & 0 & 0 & 0 & 11 \\
\hline \multirow{7}{*}{$\begin{array}{l}\text { Délnyugat- } \\
\text { Németország } \\
\text { (Magdalénien) }\end{array}$} & Monruz & 1 & 3 & 0 & 0 & 30 & 79 & 7 & 18 & 0 & 0 & 38 \\
\hline & Kohlerhöhle felső réteg & 20 & 50 & 0 & 0 & 2 & 5 & 18 & 45 & 0 & 0 & 40 \\
\hline & Hohlenberg höhle 3 & 14 & 41 & 0 & 0 & 0 & 0 & 20 & 59 & 0 & 0 & 34 \\
\hline & Petersfels (1927-32-es & 4 & 3 & 0 & 0 & 0 & 0 & 115 & 82 & 21 & 15 & 140 \\
\hline & feltárás) & & & & & & & & & & & \\
\hline & $\begin{array}{l}\text { Petersfels (1974-76-os } \\
\text { feltárás) }\end{array}$ & 18 & 16 & 18 & 16 & 40 & 37 & 31 & 29 & 2 & 2 & 109 \\
\hline & Felsställe IIIb & 0 & 0 & 0 & 0 & 44 & 76 & 5 & 9 & 9 & 15 & 58 \\
\hline
\end{tabular}

a - töredékek nélkül; b - töredékek nélkül, csak harmadidőszaki vázak;

sírmellékletként), ami egyértelműen bizonyítaná az ékszer funkciót. Hazai viszonylatban ékszerként való felhasználásra leginkább közvetett bizonyítékok utalnak.

Amennyiben feltételezzük, hogy ékszerkészítés céljából gyűjtötték őket, a hazai leletanyagban található, nagyszámú, ember által nem módosított fosszilis puhatestű vázak megmunkálatlan nyersanyagként értelmezhetőek. Szob, Ipolypart esetében az ilyen vázak zöme három, depóként értelmezhető kupacban került elő Gábori M. 1964es feltárása során. A feltáró értelmezése szerint, elhelyezkedésük alapján eredetileg kis zsákokban előkészítve vártak a továbbszállításra (Gábori, 1969). Megmunkálásuk hiánya bizonyára annak tudható be, hogy az ékszerkészítés műveletsorá- 
nak korai, begyüjtést követő fázisában lehettek. A görögországi Franchthi-barlang felhalmozott, megmunkálatlan csigaházai esetében már felmerült az ötlet, hogy egyes vázakat megmunkálatlanul ragasztottak fel a ruházatra (Baysal, 2019). Ez a gondolat a szobi anyag tekintetében sem zárható ki.

A felfüggesztés nyoma az egyik legkézenfekvőbb mutatója annak, hogy egy adott fosszilis puhatestű váz ékszerként volt hordva, vagy legalább is ilyen használatot szántak neki. Ez olyan, elsősorban ember által létrehozott módosítás (leggyakrabban lyuk vagy furat), mely lehetővé teszi, hogy az ékszert felfüggesszék vagy ráerősítsék a ruházatra, esetleg közvetlenül a testre. A magyarországi leletanyagban az emberi kéz által megmunkált vázak száma meglehetősen csekély. A jelenség nem egyedi, több közép-európai felső paleolitikus lelőhelyen számos feltárt puhatestű váz megmunkálatlan (Eriksen, 2002; Nițu et al., 2019). Egyes darabokon gyakran találni olyan lyukakat, melyeket paraziták, vagy egyéb ragadozó puhatestűek vájtak (Magyar, 1991; Dulai, 2007). Ezeket a természetes lyukakat ugyancsak használhatták felfüggesztéshez. Ez az ötlet már korábban felmerült konkrét külföldi és hazai leletanyagok kapcsán is (Eriksen, 2002; Markó et al., 2018). Egyes kutatók szerint ezeknek a nem ember által létrehozott lyukaknak köszönhető, hogy a paleolitikum során felmerült a puhatestű vázak felfüggesztésének koncepciója (Baysal, 2019, 83. o.). Minden bizonnyal a felső paleolitikum emberének esztétikai érzéke nagyban befolyásolta, hogy a ragadozók által létrehozott, véletlenszerüen elhelyezkedő lyukak által tarkított váz hordása elfogadható volt-e ékszer gyanánt. Erre adhat részleges választ $\mathrm{A}$. $\mathrm{M}$. Kubicka és szerzőtársainak kutatása, miszerint nagy a valószínűsége annak, hogy a ragadozók által létrehozott lyukak egy-egy vázon a felfüggesztéshez kifejezetten kedvező részen helyezkednek el (Kubicka et al., 2017). Ezt a megállapítást szem előtt tartva érdemes lehet megvizsgálni a hazai leletanyagot. A Szob-Ipolypart lelőhelyen előkerült, legnagyobb számban jelen lévő, 302 darab Turritellából 24 darabon volt ragadozó csiga által fúrt lyuk (Dulai, 2007). A leletanyagról szóló publikációkban nincs részletezve, hogy az utóbbi darabokon a lyukak a csigaházak mely részein helyezkednek el, de mindenképpen érdemes lenne őket összevetni a korszakban használt, hasonló formájú és ember által átlyukasztott darabokkal, mint pl. a La Madeleine gyermeksírjából előkerült Turritella gyöngyökkel (Vanhaeren et al., 2004).

Az ékszer funkcióra a tárgyak festékanyaggal való borítása is utalhat. Számos példát ismerünk arra, hogy a felső paleolitikum során a személyes ékszerek felületei kész állapotukban festve voltak, túlnyomórészt okkerrel (Hromada, 1998; Baysal, 2019; Cârciumaru et al., 2019; Fernández \& Jöris, 2008). A Dunakanyar esetében Esztergom, Gyurgyalag anyagában is fel lehetett egyes Dentalium csigaházakon fedezni okkerrel való festés nyomait, de ahogy T. Dobosi V. és Kövecses-Varga E. (1991, 239. o.) megjegyzi, ez a szín akár a leleteket befoglaló földrétegnek is köszönhető. Amennyiben az ékszer funkció egyik követelménye volt a befestés, úgy az is alátámaszthatja, hogy szobi csigadepók tovább szállításra voltak előkészítve, hiszen Szob-Ipolypart lelőhelyen nem került elő okker, vagy egyéb színezésre alkalmas anyag (Markó 2007, 7-21. o.). Mogyorósbánya-Újfalusi-dombok lelöhelyen ellenben nagy mennyiségü okker került elö, így feltehetően ezen a helyen történhetett ilyen munkafolyamat (T. Dobosi, 2015; Markó et al., 2018). Figyelembe véve, hogy a mogyorósbányai leletanyag tartalmaz néhány megmunkált puhatestű vázat, köztük olyan darabokat, melyen a lyukasztást nem fejezték be, illetve olyat, ami eltörött a kialakítás során, joggal feltételezhetjük, hogy a lelőhelyen az ékszerkészítés teljes munkafolyamatát végezték (Markó et al., 2018). Azt, hogy a két, hasonló időhorizontot, valamint azonos kulturális egységet képviselő Szob 
és Mogyorósbánya telepeinek funkciója az ékszerkészítés és a nyersanyag beszerzés szempontjából elkülöníthető, a retusált kőeszközök mennyisége és azok tipológiai összetételük arányainak eltérése is indokolhatja (T. Dobosi, 2002, 2014). Ugyanakkor a már korábban említett eltérés a puhatestű vázak nemeinek összetételét illetően nem utal rá, hogy a két lelőhelyet esetleg ugyan az a közösség használta volna.

T. Dobosi V. 1984-es cikkében Esztergom, Gyurgyalag Dentalium vázai kapcsán az önékesítés mellett a fizetőeszköz funkciót is felveti Észak-Amerika északkeleti partvidékén élt őslakosok etnográfiai jellegzetességeire támaszkodva ( $\mathrm{T}$. Dobosi, 1985, 29. o.). A jelenség nem egyedülálló a természeti népek körében. Szintén az Újvilágból ismerünk rá példát, hogy az i.sz. 12-13. század során Kaliforniában élt csumas őslakosok Olivella csigaházakból készült gyöngyöket használtak fizetőeszközként. Igaz, ez a fajta „pénz” a gazdaságuk fejlettebb szakaszában vált általánossá (Nigra \& Arnold, 2013). A felső paleolitikum puhatestü vázait illetően a fizető vagy csereeszköz funkciót nehezebb bizonyítani, mint az ékszer/dekoratív funkciót. A csumasok fizetőeszközeiből kiindulva abban az esetben valószínűbb, hogy ilyen tárgyakat egyfajta 'pénzként' használták, ha formájuk általánosított volt és széles körben voltak elterjedve a társadalmon belül (Gamble, 2020). Ezek a kritériumok a Dunakanyar puhatestű váz összetételeire nem jellemzők.

Kagylóhéjak, valamint egyszerűbb formájú csigaházak alakjukból kifolyólag különféle praktikus funkciókat is elláthattak. Sajnálatos módon, ahogy az ékszer célú felhasználásra, úgy az esetleges eszközként való használatra sincsen közvetlen bizonyítékunk a hazai leletanyagból. Külföldi párhuzamok azonban szolgálhatnak ehhez is támpontként. Pavlov I lelőhelyén egy Spondylus kagylóhéj egyfajta edényként szolgált festék előállításához (Svoboda, 1999, 196. o., Obr. 79). A dél-spanyolországi Nerja-barlang Epimagdalénien rétegeiből előkerült Pecten és Ostrea kagylók megégett felületéből ítélve lámpásként lehettek használva (Pardo et al., 2016). A francia Périgordien kultúr-komplexumban meglévő nagyobb méretű kagylók, főleg a Pecten és Cardium nembe soroltak elsősorban használati tárgyak lehettek, amire az egyes darabokon látható sérülések is utalnak (Hladilová, 2005).

Bizonyos esetekben a puhatestűek vázai átalakított eszközök alapanyagául is szolgálhattak. Az észak-spanyolországi Fuente de Salín-barlang Gravettien rétegeiben Patella vulgata (közönséges csészecsiga) vázaiból készített eszközök kerültek elő, melyekről traszeológiai vizsgálatok alapján megállapították, hogy okker feldolgozásához használták őket. Ugyanebből a leletanyagból csészecsiga vázból készült fúrót bőr megmunkálásához használtak (Cuenca-Solana et al., 2013). Több recens etnográfiai példát is ismerünk arra, hogy puhatestűek vázai eszközként vagy eszközök alapanyagaként szolgáltak, pl. a tűzföldi selk'namok Mytilus kagylókból késeket készítettek, az Amazonas-medencében pedig a gumifa lecsapolt nedvét hagyományosan Ampullaria gigas csigaházakba gyüjtötték (Cuenca-Solana et al., 2011). Ugyan a hazai paleolitikus leletanyagból nem ismerünk eszközt, ami puhatestű váz töredékeiből lett volna kialakítva, mindenesetre egyes jobb megtartású daraboknál felvethető akár ez a szándék is. Ez olyan, nemek tekintetében heterogén összetételnél, mint a Szobon előkerült kagylók esetében (nyolc különböző kagylónem fordult elő kis menynyiségben) is valószínűsíthető (Dulai, 2007, Table 1). Ha ezek a modern rendszertani különbségek a korabeli emberek számára is feltűnő eltérést jelentettek, a hétköznapi felhasználás esetében a praktikusság fontosabb lehetett, mint az egységes forma.

Hazai viszonylatban közvetett és egyben vitatható bizonyítékként szolgálhat Tiszaörvény, Varjashátnál, a Tisza hordalékából előkerült, pleisztocén korúnak gondolt, jávorszarvas agancs- 
rózsájából kialakított, csonkakúp alakú csésze (T. Dobosi, 1985). Amennyiben ezt azért készítették, hogy a fenti példákból kiindulva akár festékanyagot vagy világításra alkalmas állati zsiradékot tároljanak benne, úgy a hasonló űrtartalommal rendelkező kagylók esetében is felvethető ez a funkció. Ilyen a varjasháti csészéhez hasonló méretű fosszilis Glycymeris obovata kagylóhéj, mely a nagykovácsi Remete-Felső-barlang késői középső paleolit rétegéből került elő (Gáboriné-Csánk, 1984).

Az egyértelmű bizonyítékok megléte ellenére, a fenti adatok alapján a hazai felső paleolit lelőhelyeken előkerült puhatestű vázak nagy részének valószínűsíthető funkciója ékszer vagy legalábbis dekorációként való felhasználás, vagy az az iránti szándék lehetett.

\section{Konklúzió}

A hazai felső paleolit leletanyag tekintetében további kérdés merülhet fel annak kapcsán, hogy miért egy viszonylag kis földrajzi térségben koncentrálódnak a puhatestű vázak. Kézenfekvő magyarázat erre a kiaknázott nyersanyagforrások közelsége, melyet a megmunkálatlan darabok nagy aránya is alátámaszthat. Érdekes módon Európában több olyan térség is van, ahol az ékszerként használt puhatestű vázak (vagy akár egyéb anyagból készült ékszerek) nagy mennyiségben előfordulnak. Ilyenek Dél-Morvaország vagy Délnyugat-Németország, melyek olyan központi területekként vannak számon tartva, ahol több különböző csoport találkozott és a kulturális interakciók megtörténtek (Eriksen, 2002; Svoboda, 2007). Így hazai viszonylatban is akkor kapnak leginkább értelmet ezek a tárgyak, ha ékszerekként tekintünk rájuk. Hasznuk a szakma egyik legelterjedtebb nézete szerint a szociális és az egyéni identitás kifejezéséhez és ennek közvetítéséhez köthető (Baysal, 2019). S. L. Kuhn és szerzőtársai véleménye, hogy a vizuális kommunikáció egy formájaként elsősorban olyan területeken ékesítik magukat az emberek, ahol nagy az esélye az idegenekkel való találkozásnak, és előnnyel jár az identitás illetve a státusz kimutatása (Kuhn et al., 2001, 7645. o.). Amennyiben feltételezzük, hogy az eltérő formai preferenciák mögött eltérő szociális identitás húzódhat, úgy elképzelhető, hogy a Dunakanyar egy olyan terület volt, ahol egymástól eltérő társadalmi-kulturális azonosságtudattal rendelkező csoportok fordultak meg, és aknázták ki a helyi nyersanyag-forrásokat. Ez különösen igaz lehet, ha számolunk Lengyel Gy. elméletével, miszerint a korai Epigravettien során a Kárpát-medence refúgiumként funkcionált, hiszen ez indokolhatta az eltérő önazonosítással rendelkező közösségek egymáshoz közeli jelenlétét.

\section{The role of mollusc shells in the Carpathian Basin during the Upper Palaeolithic}

Within the context of the Paleolithic of Hungary the most abundant finds that do not bear any obvious practical function are tertiary fossil molluscs. The scientific consensus is that these were used as personal ornaments expressing social identity. This paper's goal is to shed light on the problems related to the mollusc shell find assemblages. This study touches on the discussed finds' raw material sources and their role in the settlement of a specific region, the differences and relations between the mollusc shell assemblages, the importance of certain form preferences, and the problem of the possible function of these items. This work also raises attention to the question of geographical location. The mollusc shell find assemblages are concentrated to the Danube bend area. It's overall conclusion is that assemblages with diverse form preferences imply different social identities. Their situation within a relatively small territory could indicate a refuge area where the meeting of groups with distinct self-identification was commonplace. 


\section{Felhasznált irodalom}

Bahn, P. G. (2016). Images of the Ice Age. Oxford University Press.

Bar-Yosef Mayer, D. E. (2005). The Exploitation of Shells as Beads in the Palaeolithic and Neolithic of the Levant. Paléorient, 31(1), 176-185.

Baysal, E. L. (2019). Personal Ornaments in Prehistory: An Exploration of Body Augmentation from the Palaeolithic to the Early Bronze Age. Oxbow Books.

Cârciumaru, M., Nițu, E.-C., Obadă, T., Cîrstina, O., Covalenco, S., Lupu, F. I., Leu, M., \& Nicolae, A. (2019). Personal Ornaments in the Mid Upper Palaeolithic East of the Carpathians. PALEO. Revue d'archéologie Préhistorique, 30-1, 80-97. https://doi.org/10.4000/paleo.4446

Cuenca-Solana, D., Gutiérrez-Zugasti, F. I., González-Morales, M. R., Setién-Marquinez, J., Ruiz-Martinez, E., García-Moreno, A., \& Clemente-Conte, I. (2013). Shell Technology, Rock Art, and the Role of Marine Resources during the Upper Paleolithic. Current Anthropology, 54(3), 370-380. https://doi.org/10.1086/670325

Dulai, A. (2007). Late Palaeolithic fossil collectors: Small piles of molluscs at Szob (Börzsöny Mts, North-Hungary). Folia Archaeologica, 53, 23-26.

Eriksen, B. V. (2002). Fossil mollusks and exotic raw materials in late glacial and early postglacial -a complement to lithic studies. In L. E. Fisher \& B. V. Eriksen (Szerk.), Lithic raw material economies in late glacial and early postglacial Europe / edited by Lynn E. Fisher, Berit Valentin Eriksen. (pp. 27-52). Archaeopress.

Fernández, E. Á., \& Jöris, O. (2008). Personal ornaments in the Early Upper Paleolithic of Western Eurasia: An evaluation of the record. Eurasian Prehistory, 5(2), 31-44.

Gábori, M. (1969). Paläolithische Schnecken-Depots von Szob. Acta Archaeologica Academiae Scientiarum Hungaricae, 21, 21-48.
Gamble, L. H. (2020). The origin and use of shell bead money in California. Journal of Anthropological Archaeology, 60, 101237. https://doi. org/10.1016/j.jaa.2020.101237

Hladilová, Š. (2005). Chapter III.8. Tertiary fossils, especially molluscs. In J. Svoboda (Szerk.), Pavlov I - Southeast. A window into the Gravettian lifestyles.: Köt. D (pp. 374-390). Archeologický ústav AV ČR Brno. https://is. muni.cz/publication/800515/en/Pavlov-I-Southeast-A-window-into-the-Gravettian-lifestyles/Svoboda

Hladilová, Š. (2011). Tertiary and Quaternary molluscs from the Pavlov VI site. In Pavlov, excavations 2007-2011 (pp. 54-60). Academy of Sciences of the Czech Republic, Institute of Archaeology at Brno - Polish Academy of Sciences, Institute of Systematics and Evolution of Animals.

Hromada, J. (1998). Gravettienske sídliská v Moravanoch nad Váhom a ich miesto vo vývoji mladého paleolitu strednej Európy. Slovenská Archaológia, 46(2), 145-167.

Jordá Pardo, J. F., Aura Tortosa, J. E., Avezuela Aristu, B., Álvarez-Fernández, E., García-Pérez, A., \& Maestro, A. (2016). Breaking the waves: Human use of marine bivalves in a microtidal range coast during the Upper Pleistocene and the Early Holocene, Vestíbulo chamber, Nerja Cave (Málaga, southern Spain). Quaternary International, 407, 59-79. https://doi.org/10.1016/j.quaint.2015.12.089

Kilburn, R. N. (1981). Revision of the genus Ancilla Lamarck, 1799 (Mollusca: Olividae: Ancillinae). Annals of the Natal Museum, 24(2), 349463. https://doi.org/10.10520/AJA03040798_544 Kubicka, A. M., Rosin, Z. M., Tryjanowski, P., \& Nelson, E. (2017). A systematic review of animal predation creating pierced shells: Implications for the archaeological record of the Old World. PeerJ, 5, e2903. https://doi.org/10.7717/ peerj.2903 
Kuhn, S. L., Stiner, M. C., Reese, D. S., \& Güleç, E. (2001). Ornaments of the earliest Upper Paleolithic: New insights from the Levant. Proceedings of the National Academy of Sciences, 98(13), 7641-7646. https://doi.org/10.1073/ pnas. 121590798

Lengyel, Gy. (2010). An aspect to the re-evaluation of Ságvár (Lyukas domb) Upper Palaeolithic site. Folia Archaeologica, 54, 25-37.

Lengyel, Gy. (2018). Lithic analysis of the Middle and Late Upper Palaeolithic in Hungary. Folia Quaternaria, 86, 5-157. https://doi.org/10.4467 /21995923FQ.18.001.9819

Magyar, I. (1991). Palaeolithic Trinkets in Esztergom-Gyurgyalag. Acta Archaeologica Academiae Scientiarum Hungaricae, 43, 265-266.

Magyar Nemzeti Digitális Archívum. (n.d.a). Charonia apenninica. Gerinctelen ösmaradvány. Magyar Nemzeti Digitális Archívum. https://mandadb.hu/tetel/684892/

Magyar Nemzeti Digitális Archívum. (n.d.b). Murex partschi. Gerinctelen ösmaradvány. Magyar Nemzeti Digitális Archívum. https://mandadb. hu/tetel/702988/

Magyar Nemzeti Digitális Archívum. (n.d.c). Strombus bonellii. Gerinctelen ôsmaradvány. Magyar Nemzeti Digitális Archívum. https://mandadb.hu/tetel/684880/

Markó, A. (2007). The Upper Palaeolithic site at Szob. Folia Archaeologica, 53, 7-22.

Markó, A., Dulai, A., \& T. Dobosi, V. (2018). ‘... Finding a smoother pebble or prettier shell than ordinary' - Non-utilitarian artefacts in the upper palaeolithic - A case study from Mogyorósbánya (Transdanubia, Hungary). Acta Archaeologica Academiae Scientiarum Hungaricae, 69(2), 227-252. https://doi. org/10.1556/072.2018.69.2.1

Nigra, B. T., \& Arnold, J. E. (2013). Explaining the monopoly in shell-bead production on the Channel Islands: Drilling experiments with four lithic raw materials. Journal of Archaeo- logical Science, 40(10), 3647-3659. https://doi. org/10.1016/j.jas.2013.04.021

Nițu, E.-C., Cârciumaru, M., Nicolae, A., Cîrstina, O., Lupu, F. I., \& Leu, M. (2019). Mobility and social identity in the Mid Upper Paleolithic: New personal ornaments from Poiana Cireșului (Piatra Neamț, Romania). PLOS ONE, 14(4), e0214932. https://doi.org/10.1371/journal. pone.0214932

Peters, H., O'Leary, B. C., Hawkins, J. P., Carpenter, K. E., \& Roberts, C. M. (2013). Conus: First Comprehensive Conservation Red List Assessment of a Marine Gastropod Mollusc Genus. PLOS ONE, 8(12), e83353. https://doi. org/10.1371/journal.pone.0083353

Rigaud, S., Costamagno, S., Pétillon, J.-M., Chalard, P., Laroulandie, V., \& Langlais, M. (2017). Settlement dynamic and beadwork: New insights on the Late Upper Paleolithic craft activities. PaleoAnthropology, 137-155. https:// doi.org/10.4207/PA.2019.ART128

Solana, D. C., Zugasti, I. G., \& Conte, I. C. (2011). The Use of Mollusc Shells as Tools by Coastal Human Groups: The Contribution of Ethnographical Studies to Research on Mesolithic and Early Neolithic Technologies in Northern Spain. Journal of Anthropological Research, 67(1), 77-102. https://doi.org/10.3998/ jar.0521004.0067.105

Stiner, M. C. (2014). Finding a Common Bandwidth: Causes of Convergence and Diversity in Paleolithic Beads. Biological Theory, 9(1), 5164. https://doi.org/10.1007/s13752-013-0157-4

Svoboda, J. A. (1999). Čas lovců: Déjiny paleolitu, zvláště na Moravě. Archeologcký ústav Akademie věd Česke republiky.

Svoboda, J. A. (2007). The Gravettian on the Middle Danube. PALEO. Revue d'archéologie Préhistorique, 19, 203-220.

T. Dobosi, V. (1985). Jewelry, musical instruments and exotic objects from the Hungarian Paleolithic. Folia Archaeologica, 36, 7-42. 
T. Dobosi, V. (1993). Jászfelsőszentgyörgy-Szunyogos, felsőpaleolit telep. Tisicum. A Jász-Nagykun-Szolnok Megyei Múzeumok Évkönyve, 8, 41-60.

T. Dobosi, V. (2002). Mogyorósbánya, Újfalusi dombok, felső paleolit telep. Régészeti Kutatások Magyarországon, 1999, 5-15.

T. Dobosi, V. (2009). A hazai felső paleolitikum vázlata. Tisicum. A Jász-Nagykun-Szolnok Megyei Múzeumok Évkönyve, 19, 13-29.

T. Dobosi, V. (2014). A Dunakanyar felső paleolitikuma. Archaeologiai Értesitô, 139, 7-34. https:// doi.org/10.1556/ArchErt. 139.2014.1

T. Dobosi, V. (2015). Mogyorósbánya-Újfalusi-dombok, zárójelentés. Litikum - a Kökor Kerekasztal Folyóirata, 3, 5-12.

T. Dobosi, V., \& Holl, B. (2013). A gravetti telepek topográfiája (Topography of Gravettian sites). Litikum - a Kökor Kerekasztal folyóirata, 1, 6682.

T. Dobosi, V., \& Kövecses-Varga, E. (1991). Upper Palaeolithic site at Esztergom-Gyurgyalag. An archaeological analysis. Acta Archaeologica Academiae Scientiarum Hungaricae, 43, 233-255.

T. Dobosi, V., \& Vörös, I. (1987). The Pilisszántó I. Rock-shelter revision. Folia Archaeologica, 38, 7-62.

Vanhaeren, M., d'Errico, F., Billy, I., \& Grousset, F. (2004). Tracing the source of Upper Palaeolithic shell beads by strontium isotope dating. Journal of Archaeological Science, 31(10), 14811488. https://doi.org/10.1016/j.jas.2004.03.011

Wiśniewski, A., Płonka, T., Jary, Z., Lisa, L., Traczyk, A., Kufel-Diakowska, B., Raczyk, J., \& Bajer, A. (2015). The early Gravettian in a marginal area: New evidence from SW Poland. Quaternary International, 359-360, 131-152. https://doi.org/10.1016/j.quaint.2014.10.003 


\section{A tealevelektöl} a levélhegyekig

TANULMÁNYOK

MESTER ZSOLT TISZTELETÉRE

60. SZÜLETÉSNAPJA ALKALMÁBÓL
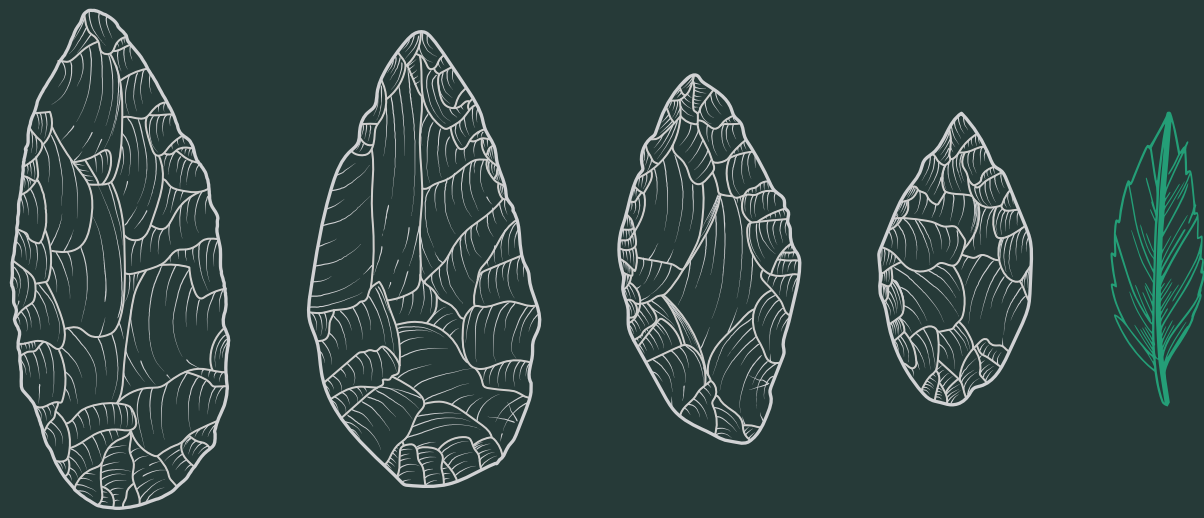

SZERKESZTŐK:

FARAGÓ NORBERT

KIRÁLY ATTILA

SZEGEDI KRISTÓF ISTVÁN 

LITIKUM KÖNYVTÁR 1. 

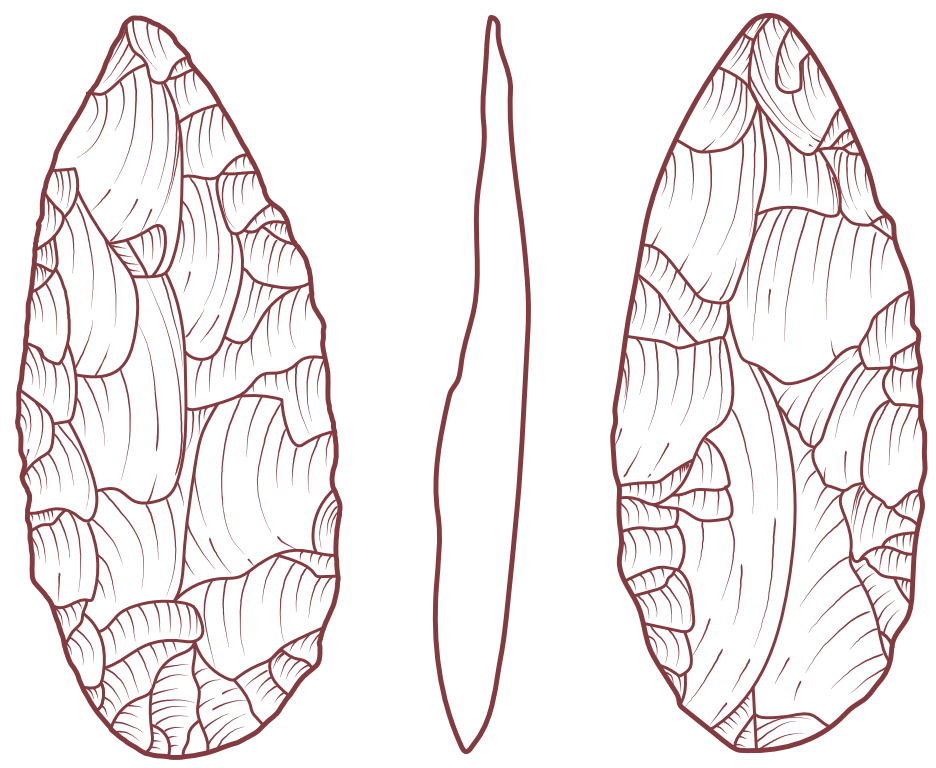

$3 \mathrm{~cm}$

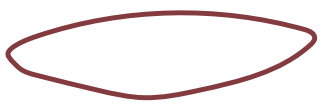

Szeletai levéleszköz

Kozłowski et al., 2009, Planche 11 nyomán. 


\title{
A tealevelektöl a levélhegyekig
}

\author{
TANULMÁNYOK \\ MESTER ZSOLT TISZTELETÉRE \\ 60. SZÜLETÉSNAPJA ALKALMÁBÓL
}

Szerkesztők:

Faragó Norbert

Király Attila

Szegedi Kristóf István
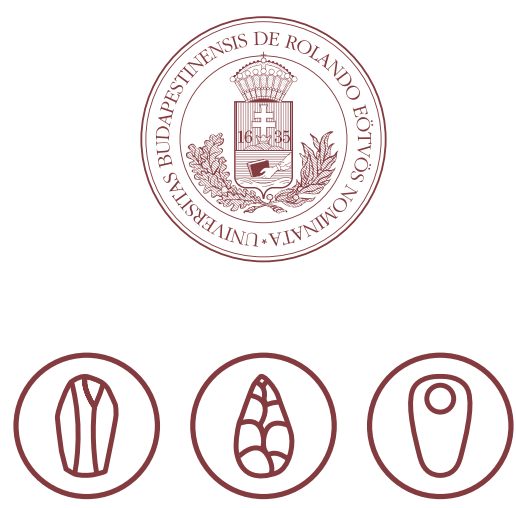

LITIKUM - A KŐKOR KEREKASZTAL FOLYÓIRATA

ELTE BTK RÉGÉSZETTUDOMÁNYI INTÉZET

2021 
A TEALEVELEKTŐL A LEVÉLHEGYEKIG TANULMÁNYOK MESTER ZSOLT TISZTELETÉRE 60. SZÜLETÉSNAPJA ALKALMÁBÓL

LITIKUM KÖNYVTÁR 1.

Kiadó:

Litikum - a Kőkor Kerekasztal Folyóirata

ELTE BTK Régészettudományi Intézet

Felelős kiadó:

Király Attila - szerkesztő, Litikum - a Kőkor Kerekasztal Folyóirata

3524 Miskolc, Jósika M. u. 20.•attila@litikum.hu•https://litikum.hu

Felelős szerkesztők:

FARAGÓ NORBERT, KIRÁLY ATTILA, SZEGEDI KRISTÓF ISTVÁN

Sorozatszerkesztő:

KIRÁLY ATTILA

Grafikai terv, tördelés, borítóterv:

KIRÁLY ATTILA

ISBN (PDF): 978-615-01-1676-1

ISBN (puhafedelű): 978-615-01-1675-4

(C A szerkesztők és a szerzők, 2021 • A kötet a Creative Commons Nevezd meg! - Ne add el! - Így add tovább! 4.0 Nemzetközi Licenc feltételeinek megfelelően használható fel. A mű szabadon használható, terjeszthető és sokszorosítható az eredeti szerző és forrás megjelölése mellett. A feldolgozott, átalakított származékos mű az eredeti licenszfeltételekkel terjeszthető. @(1)@(?

A kötet első nyomása FR4 alakban, tíz nyomtatott példányban készült a Source Sans Pro és Source Serif Pro betűtípusok felhasználásával, melyek az SIL Open Font licensz alá esnek. A kiadvány print-on-demand módon érhető el a felelős kiadótól vagy a Litikum szerkesztőségében.

Nyomta és kötötte: Vareg Nyomda. 


\section{TARTALOMJEGYZÉK}

Köszöntő

VIDA TIVADAR

Mester Zsolt publikációi - bibliográfia 1989-2020

KIRÁLY ATTILA

Társadalmi folyamatok a kőeszköz-kutatásban. A chaîne opératoire koncepció használata újkőkori kőanyagok vizsgálatában

SZILÁGYI KATA

A fosszilis puhatestű vázak szerepének kérdése a magyarországi felső paleolitikumban

BÁLINT CSABA

Demjén-Szőlő-hegy III korai felső paleolit lelőhely

BÉRES SÁNDOR ÉS KEREKES DALMA

Technológiai megfigyelések a rákóczifalvi temető

bifaciális levélhegyén

FARAGÓ NORBERT

Nagykovácsi-Remete-barlang 10. rétegének időrendi kérdései

SZEGEDI KRISTÓF ISTVÁN

Acsa-Rovnya vakaróinak komplex vizsgálata - felszíni

leletegyüttesek a felső paleolitikus tájhasználat

rekonstrukciójában

KIRÁLY ATTILA 